IJMS 27(2), 1-26 (2020)

How to cite this article:

Abdin, F., Ismail, A., Muhamad, N. S., \& Nor, A. M. (2020). Effect of perceived fairness in pay system on work-related attitude. International Journal of Management Studies, 27(2) July, 1-26.https://doi.org/10.32890/ijms.27.2.2020.7792

\title{
EFFECT OF PERCEIVED FAIRNESS IN PAY SYSTEM ON WORK-RELATED ATTITUDE
}

\author{
FATMAWATI ABDIN \\ Institute of Islam Hadhari, Universiti Kebangsaan Malaysia
}

AZMAN ISMAIL*

NUR SA'ADAH MUHAMAD

Faculty of Economics and Management

Universiti Kebangsaan Malaysia

AZMAWATY MOHAMAD NOR

Faculty of Education, University of Malaya

*Corresponding author: azisma12@ukm.edu.my

\begin{abstract}
Perceived fairness in pay system has two critical features, namely procedural fairness and distributive fairness. Recent studies have shown that the capability of employers to propose and administer pay systems appropriately, including allocating pay and determining the value of pay in a fair manner, has a positive association with employees' work-related attitude. Although this association has been well-researched, the role of perceived fairness as a vital predicting variable of work-related attitude, particularly towards job satisfaction and organizational commitment, has still not been thoroughly deliberated. Hence, this study fills this gap. Self-report survey questionnaires were collected from the employees of a public audit agency in Peninsular Malaysia. Smart PLS software was utilized to assess the quality of the research instrument and test the research hypotheses. The results of hypothesis testing confirm that perceived procedural fairness and distributive fairness in managing the pay system, are important determinants of job satisfaction
\end{abstract}


and organizational commitment in the examined organization. Additionally, this study offers useful guidelines for practitioners to improve the pay management system and proposes future studies.

Keywords: Procedural fairness, distributive fairness, pay system, job satisfaction, organizational commitment.

Received: 29/12/2019 Revised: 10/7/2020 Accepted: 15/7/2020 Published: 11/10/2020

\section{Introduction}

Organizations use different terms when referring to their pay system. This variation is observable not only across organizations in different parts of the world, but also within the same country. Among the widely used terms are compensation, reward, remuneration, salary and wages, all of which refer to the same thing (Martocchio, 2019; Newman, Cinelli, Vorhies, \& Folse, 2019). From the human resource management view point, pay system is interpreted as employers giving several types of reward to employees, such as monetary returns (e.g., salary and bonus), benefits (e.g., leave, health care and income protection), and relational returns (e.g., recognition and status, nonroutine work and opportunity for learning and self-development). In determining pay for employees, most successful organizations utilize two major award bases, namely pay for work (e.g., rewards based on employees' job, seniority or duration of employment), and pay for performance (e.g., monetary rewards based on employees' competencies, merit and/or productivity) (Ismail \& Razak, 2017; Newman et al., 2019). Both these award bases are equally important and may complement each other in supporting the vision and mission of the organization (Milkovich \& Newman, 2009; Razak \& Ismail, 2018).

Nonetheless, even where the reward system is designed and administered based on standard rules and regulations, its effectiveness may be strongly influenced by the management style in the organization. In practice, for example, the willingness of managers to avoid political behaviour and/or personal judgments in evaluating employees' performance, would invoke employees' perception that their rewards are fairly determined based on proper procedures and 
distribution rules in the organization. Further, the level of perceived fairness in pay procedures and distribution differs among employees even within the same organization. For example, employees will perceive fairness if they know that their pay is determined based on proper procedures and the rewards that they receive are equally allocated according to their contribution. Furthermore, these fairness perceptions can encourage employees to improve their work, which would lead to an increased positive work-related attitude.

Despite extensive studies on perceived fairness in the context of the organization, researchers have argued that its role in pay systems has still not been adequately discussed (Anuar, Ismail, \& Abdin, 2014; Munir, Aziz, Shaladin, \& Muhammad, 2013), possibly due to several reasons: first, previous studies have focused on the internal aspects of perceived fairness, such as its conceptual definition, importance, and type (Ali \& Saifullah, 2014; Rahman, Shahzad, Mustafa, Khan, \& Qurashi, 2016); and second, extant empirical research has utilized modest and direct effect models to evaluate separate relationships between two variables, i.e., the relationship between employee attitude and perceived fairness in pay systems; and the relationship between perceived fairness in specific pay types and a particular work-related attitude (e.g., turnover intention, satisfaction, commitment) (Anuar et al., 2014; Colquitt, Conlon, Wesson, Porter, \& Ng, 2001).

Furthermore, existing models have been measured using simple behavioural statistics which could display the nature and degree of relationships between the variables, but which neglect the effect size and nature of perceived fairness in pay systems as a crucial predicting variable (Rehman, Rehman, Khan, Saeed, Adeel, \& Tariq, 2015; Rahman et al., 2016). Due to the complexity of this issue, these general findings may not translate well into practical recommendations, in particular, for the purpose of formulating fair pay management systems, which are very much needed to support the strategies and objectives of the organization, amidst the intense global competition (Naqvi, Kanwal, Ishtiaq, \& Ali, 2013; Rehman et al., 2015). Hence, this study elucidates this conundrum by measuring the effect of perceived fairness on work-related attitude in the context of pay management systems. The study's objective is four-prone, namely, to evaluate the relationships between: a) procedural fairness and job satisfaction; b) distributive fairness and job satisfaction; c) procedural fairness 
and organizational commitment; and d) distributive fairness and organizational commitment.

\section{Literature Review}

Past studies on organizational compensation have found that perceived fairness in pay systems leads to higher positive work-related attitude, including organizational commitment and job satisfaction (Abbasi \& Alvi, 2012; Cohen-Charash \& Spector, 2001; Colquitt, 2001). Perceived fairness in pay systems consists of two major categories, namely: a) procedural fairness, which concerns fairness in the process of distributing pay to employees (Erdogan, Kraimer, \& Liden, 2001); and b) distributive fairness, which emphasizes on the fairness in determining outcome values that are commensurate with employee contributions (Colquitt, Zapata-Phelan, \& Roberson, 2005; Folger \& Cropanzano, 1998; George \& Wallio, 2017; Nabatchi, Bingham, \& Good, 2007). According to the organizational behaviour viewpoint, job satisfaction is normally assessed based on cognitive and/or affective paradigms, in the sense that employees who have positive thinking after assessing their job or positive emotions about the job that they do, are considered satisfied (Colquitt, LePine \& Wesson, 2017; Robbins \& Judge, 2007). This is because job satisfaction may consist of intrinsic job aspects (such as job prospects and ability to use a variety of skills in doing daily work); or extrinsic job aspects (such as satisfaction with their superiors, co-workers, reward and work environment) (Bakhshi, Kumar, \& Rani, 2009); Yahya, Johari, Adnan, Mohd-Isa, \& Daud, 2008; Misener, Haddock, Gleaton, \& Ajamieh, 1996). If employees feel satisfied with any of their job aspects, this may induce a higher satisfaction with their job.

Conversely, organizational commitment is usually defined as a psychological bond between employees and the organization. It comprises three major types, namely continuance commitment (employees' feelings that they obtain more gains if they stay with their organization); affective commitment (employees' positive emotional attachment to the organization); and normative commitment (employees' obligatory feelings to stay with their organization). If employees have a high degree of continuance, normative, and affective commitment, they will also have high level of attachment 
to their organization (Allen \& Meyer, 1990; Robbins \& Judge, 2007; Yahya et al., 2008).

The influence of perceived fairness in pay systems in changing workrelated attitude can be explained by several theories on organizational fairness. Leventhal's (1980) Procedural Fairness Theory, for example, suggests six fairness rules in the process and system of distributing pay to employees, namely: a) consistency (i.e., across employees and across time); b) impartiality (i.e., free from vested interest); c) accuracy (i.e., right information used to make decisions); d) representativeness (i.e., seeking opinions of various groups in making decisions); e) correctability (i.e., establishment of mechanisms to correct inaccurate decisions); and f) ethical standards (i.e., compliance to ethical and moral standards). Therefore, when employees perceive their pay has been determined fairly, a more positive behaviour is demonstrated. Conversely, Adams' (1963) Equity Theory highlights the balance between employees' input (such as work contribution) and output (such as reward) in the organizational exchange and distribution. Perceived fairness will be enhanced if employees feel that equity is not violated, i.e., the value of pay equals their contribution (Adams, 1963; 1965). Therefore, if an individual receives lower output in comparison to input, the individual may adjust the way of doing work, which is perceived as commensurate, resulting in doing less work.

The relationship between perceived fairness in pay systems and workrelated attitude has been proven in several studies on organizational settings. Such studies include the survey on 2,505 participants at the University of Georgia, US (Clay-Warner, Reynolds, \& Roman, 2005); 128 staff employed in an Indian medical college (Bakhshi et al. 2009); 229 employees at an electrical industry, Jordan (Al-Zu'bi, 2010); 300 respondents at several small and medium industries in the Klang Valley, Peninsular Malaysia (Choong, Wong, \& Tioh, 2010); 150 lecturers at the University of Punjab, India (Aslam, 2012); 131 workers from the Iranian Sports Federation, in Iran (Sareshkeh, Ghaziani, \& Tayebi, 2012); 25 employees working in the banks in Balochistan (Ali \& Saifullah, 2014); 120 Gomal University's academic staff in Pakistan (Rehman et al., 2015); 38 employees at CV Tanaya Fiberglass in Surabaya, Indonesia (Kristanto, 2015); and 400 employees in the telecom sector in Pakistan (Khattak, Sindhu, Haider, \& Urooj, 2017). 
The abovementioned investigations have led to two vital discoveries. Firstly, organizations implement certain decision-making rules to ensure procedural fairness in managing pay systems, such as using consistent procedures to distribute pay, allowing employees to be involved in making pay decisions, determining pay based on employee performance, and giving opportunity to employees to express feedback and suggestions regarding pay systems. The ability of the management to distribute pay according to such procedures has led to greater positive work-related attitude, especially job satisfaction (Choong et al., 2010; Al-Zu'bi, 2010; Aslam, 2012); and organizational commitment (Bakhshi et al., 2009; Kristanto, 2015; Ali \& Saifullah, 2014; Rehman et al., 2015).

Secondly, organizations establish an equity criterion to determine distributive fairness in managing pay systems. Under this perspective, pay (e.g., pay rates, pay rise, pay levels and variable rewards) is equally distributed based on contributions from employees (e.g., ability, effort and experience); and/or performance (e.g., merit, competency and productivity). Consequently, this practice could lead to an increasingly positive work-related attitude, particularly job satisfaction (Al-Zu'bi, 2010; Clay-Warner, Reynolds, \& Roman, 2005); and organizational commitment (Ali \& Saifullah, 2014; Khattak et al., 2017; Kristanto, 2015; Rehman et al., 2015). The conceptual framework of this research is exhibited in Figure 1.

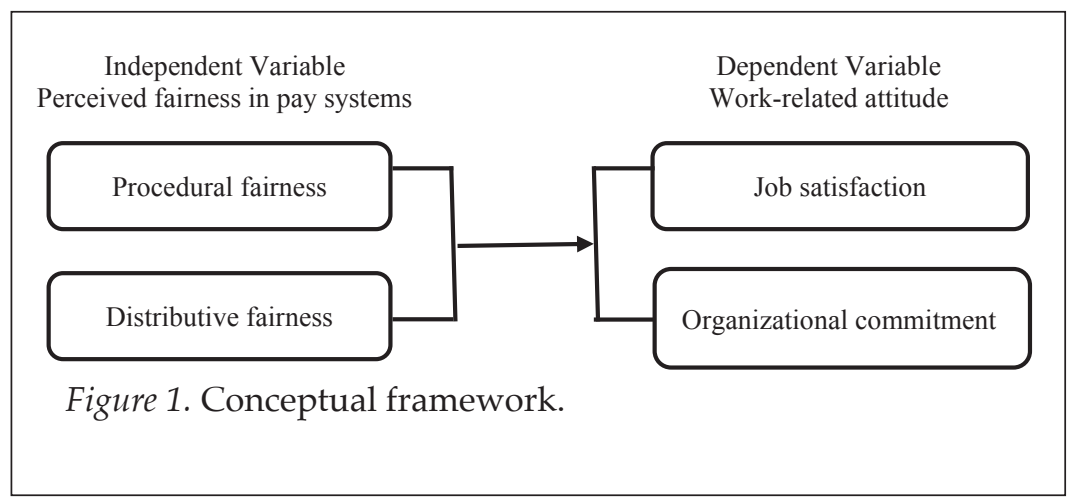

Referring to the evidence discussed above, the following hypotheses are formulated:

$\mathrm{H}_{1}$ : Procedural fairness has a positive impact on job satisfaction. $\mathrm{H}_{2}$ : Distributive fairness has a positive impact on job satisfaction. 
$\mathrm{H}_{3}$ : Procedural fairness has a positive impact on organizational commitment.

$\mathrm{H}_{4}$ : Distributive fairness has a positive impact on organizational commitment.

\section{Methodology}

\section{Research Design}

This research was carried out at the headquarters of a public audit agency in West Malaysia. The organization is an independent government agency established to carry out audit of the accounts of ministries, departments, agencies and companies under the federal and state governments of Malaysia. This organization aims to become an exemplary organization in managing audit activities. In order to empower its employees, this organization adopts the pay system issued by the Public Services Department (PSD) of Malaysia. The remuneration system outlines the level, type and/or amount of reward according to performance, duration of tenure, and academic qualifications, as well as the procedure and distribution of rewards. In general, the standard rules and regulations stipulated are meant to ensure that equity and fairness are upheld by a PSD agency (Public Service Department, 2018).

A research design using survey method was adopted, thereby ensuring accurate data collection and reduced bias, and to generally increase the quality of the data (Creswell, 2014; Sekaran \& Bougie, 2010). During initial data collection, a questionnaire was drafted in the Malay Language in accordance with literature on organizational fairness. Then, the questionnaire was translated into the English language as the back-translation technique is useful to improve the reliability and validity of the study results.

\section{Measures}

The survey questionnaire consists of two main sections. The first section deals with nine items for perceived fairness in pay systems, namely procedural fairness (PRJC) and 10 items for distributive fairness (DTBC), adapted from Greenberg et al. (2003), Ikramullah, 
Shah, Hassan, Zaman, and Khan (2011), Ismail, Madrah, Aminudin, and Ismail (2013), Moorman, Blakely and Niehoff (1998), and Walsh (2003). The second section is on attitude relating to work, namely job satisfaction (JSTN) and organizational commitment (OGCT). JSTN comprises 13 items based on Mas'ud (2004), Singh, and Sharma (1999), and Warr, Cook, and Wall (1979); while OGCT was analysed using 11 items adapted from Allen and Meyer (1996), LaMastro (1999), Jaros (2007), Hamidun (2009), and Mowday, Porter, and Steers (1982). All items were analysed using a seven-point Likert scale, ranging from "strongly disagree" / "strongly dissatisfied" (1) to "strongly agree" / "strongly satisfied" (7). Participants' characteristics were utilized as controlling variables because this research focused on employee attitude.

\section{Sample}

This study sampled the employees of the examined organization. A purposive sampling plan was employed because the details as well as total number of employees in the organization were not given due to confidentiality reasons. Consequently, the researchers could not use a randomized technique to select the respondents. The sample for this study was selected as follows: first, 500 survey questionnaires were distributed to various divisions of the examined organization. Out of this, $269(53.8 \%)$ questionnaires were returned; second, all 269 responses were selected as the research sample after determining the usability of the returned responses as well as ascertaining that all participation was voluntary; third, whether or not the sample is sufficient was calculated according to the rule of thumb, "the sample size should be equal to or larger than 10 times the largest number of structural paths directed at a particular construct in the structural model" (Hair, Hult, Ringle, \& Sarstedt, 2017), and "the measurement models have an acceptable quality of terms of outer loadings (e.g., loadings should be above the common threshold of 0.70)" (Hair et al. 2017). This study shows that DTBC has 10 items and it is the variable that has the highest number of formative indicators in the survey questionnaire. Therefore, based on the10-times rule, a minimum sample size of 100 respondents is required. Accordingly, the number of samples in this research (269) was deemed sufficient as it satisfactorily fulfils the abovementioned criteria, thus allowing it to be used to assess the hypothesized model. Next, as suggested by Eichhorn (2014) and Podsakoff, MacKenzie, Lee, and Podsakoff (2003), Burck and Peterson's (1980) single factor 
test was applied in order to observe any bias in the survey data. The outcome of the test showed a variance percentage of 45.877 , well below the $50 \%$ variance mark, hence signifying the lack of data bias in the survey.

\section{Data Analysis}

SmartPLS software was utilized as the data analysis tool as it can deliver latent variable results, handle issues related to small sample size, and evaluate complex research models (Hair et al., 2017; Reinartz et al., 2009). Following the experts' recommendations, firstly, confirmatory factor analysis was conducted to evaluate the reliability and validity of the instrument; and secondly, SmartPLS path model analysis was utilized to test the direct effects model. Based on the one-tailed test, the hypotheses were found to be significant as the t-statistics revealed a value of more than 1.65 (Hair, Hult, Ringle \& Sarstedt, 2017; Reinartz, Haenlein, \& Henseler, 2009). Furthermore, the $\mathrm{R}^{2}$ value was used as a standard to determine the model's predictive strength depending on the rule: 0.02 (weak), 0.13 (moderate), and 0.26 (substantial) (Cohen, 1988). The $\mathrm{f}^{2}$ value determines the effect size of the predicting variable of the model with the following baselines: 0.02 (weak), 0.15 (medium), and 0.35 (large) (Hair et al., 2017). Further, the standardised root mean square residual (SRMR) value of less than 0.08 (Hu \& Bentler, 1998) is used to show whether or not the model meets the model fit standard. Finally, the latent exogenous variable with a $\mathrm{Q}^{2}$ value of more than zero, ascertains the predictive relevance of the model (Hair et al., 2017).

\section{Results}

\section{Respondents' Characteristics}

Table 1 shows the majority of employees who participated in this study are female $(79.6 \%)$, aged 25 to 34 years old $(43.9 \%)$, mainly diploma holders (42.8\%) and married (85.9\%). In terms of employment, most of them are technical staff $(61.0 \%)$, are permanently employed $(98.6 \%)$, work in management sector (52.4\%), have been employed for five to 14 years $(69.9 \%)$, and earn a monthly gross income ranging from RM2,000 to RM3,999 (53.5\%). 
IJMS 27(2), 1-26 (2020)

Table 1

Respondents' Characteristics ( $n=269)$

\begin{tabular}{|c|c|c|}
\hline Characteristic & Sub-Profile & Percentage \\
\hline Gender & $\begin{array}{l}\text { Male } \\
\text { Female }\end{array}$ & $\begin{array}{l}20.4 \\
79.6\end{array}$ \\
\hline Age & $\begin{array}{l}\text { Below } 25 \text { years old } \\
25 \text { to } 34 \text { years old } \\
35 \text { to } 44 \text { years old } \\
45 \text { to } 54 \text { years old } \\
55 \text { years old and above }\end{array}$ & $\begin{array}{r}4 \\
43.9 \\
41.7 \\
8.9 \\
5.2\end{array}$ \\
\hline $\begin{array}{l}\text { Highest level of } \\
\text { education }\end{array}$ & $\begin{array}{l}\text { Lower School Certificate (SRP/PMR/ } \\
\text { LCE) } \\
\text { High School Certificate (SPM/MCE) } \\
\text { Higher School Certificate (STPM/HSC) } \\
\text { Diploma } \\
\text { Bachelor's Degree } \\
\text { Master's Degree }\end{array}$ & $\begin{array}{r}1.5 \\
8.6 \\
3.7 \\
42.8 \\
37.9 \\
5.6\end{array}$ \\
\hline Marital status & $\begin{array}{l}\text { Single } \\
\text { Married }\end{array}$ & $\begin{array}{l}14.1 \\
85.9\end{array}$ \\
\hline $\begin{array}{l}\text { Employment } \\
\text { status }\end{array}$ & $\begin{array}{l}\text { Permanent } \\
\text { Daily part-time worker }\end{array}$ & $\begin{array}{r}98.6 \\
1.4\end{array}$ \\
\hline Sector & $\begin{array}{l}\text { Management } \\
\text { Financial } \\
\text { Governance } \\
\text { Performance }\end{array}$ & $\begin{array}{r}52.4 \\
9.7 \\
21.2 \\
0.4\end{array}$ \\
\hline Position & $\begin{array}{l}\text { Professional Management } \\
\text { Supervisor } \\
\text { Technical Staff } \\
\text { Clerical and support staff } \\
\text { Others }\end{array}$ & $\begin{array}{r}33.5 \\
4.5 \\
61.0 \\
1.1 \\
16.4\end{array}$ \\
\hline $\begin{array}{l}\text { Length of } \\
\text { service }\end{array}$ & $\begin{array}{l}\text { Less than } 5 \text { years } \\
\text { 5-14 years } \\
\text { 15-24 years } \\
\text { More than } 25 \text { years } \\
\text { RM2,000 and less }\end{array}$ & $\begin{array}{r}7.1 \\
69.9 \\
13.8 \\
9.3 \\
4.5\end{array}$ \\
\hline Gross income & $\begin{array}{l}\text { RM2,000-RM3,999 } \\
\text { RM4,000-RM5,999 } \\
\text { RM6,000-RM7,999 } \\
\text { RM8,000-RM9,999 } \\
\text { RM10,000 and above }\end{array}$ & $\begin{array}{r}53.5 \\
28.7 \\
8.9 \\
3.7 \\
0.7\end{array}$ \\
\hline
\end{tabular}


IJMS 26(2), 1-26 (2020)

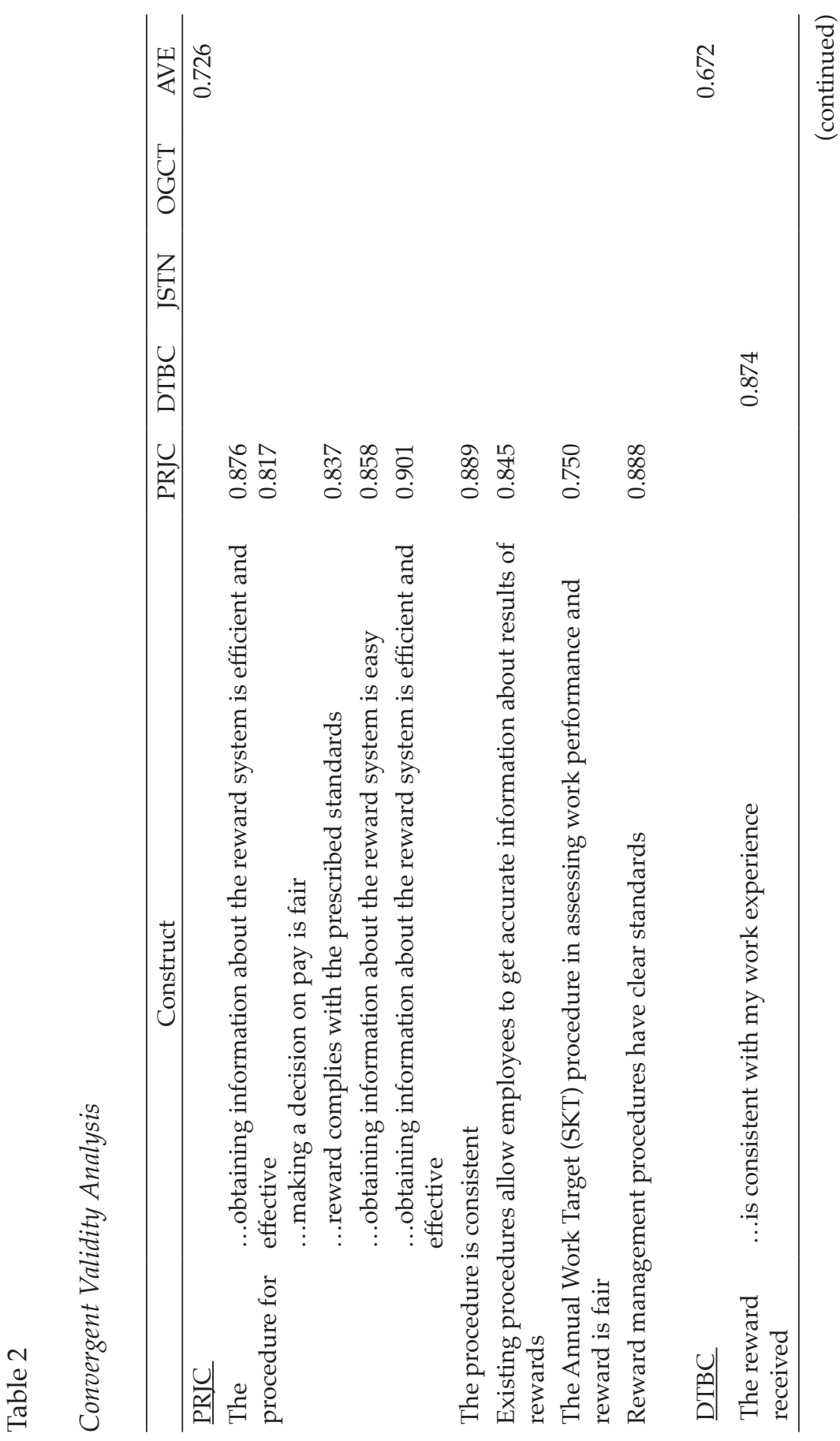


IJMS 27(2), 1-26 (2020)

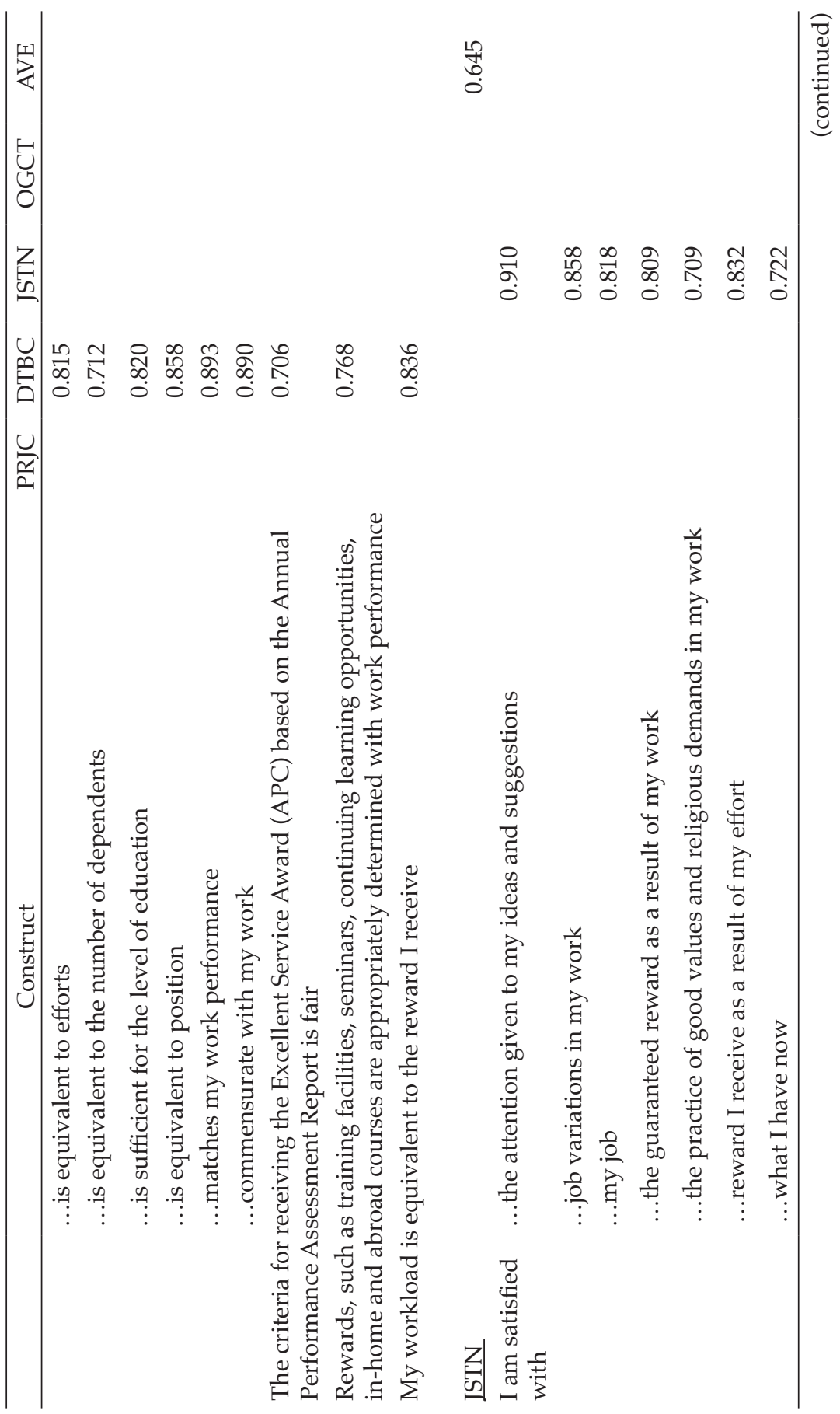


IJMS 26(2), 1-26 (2020)

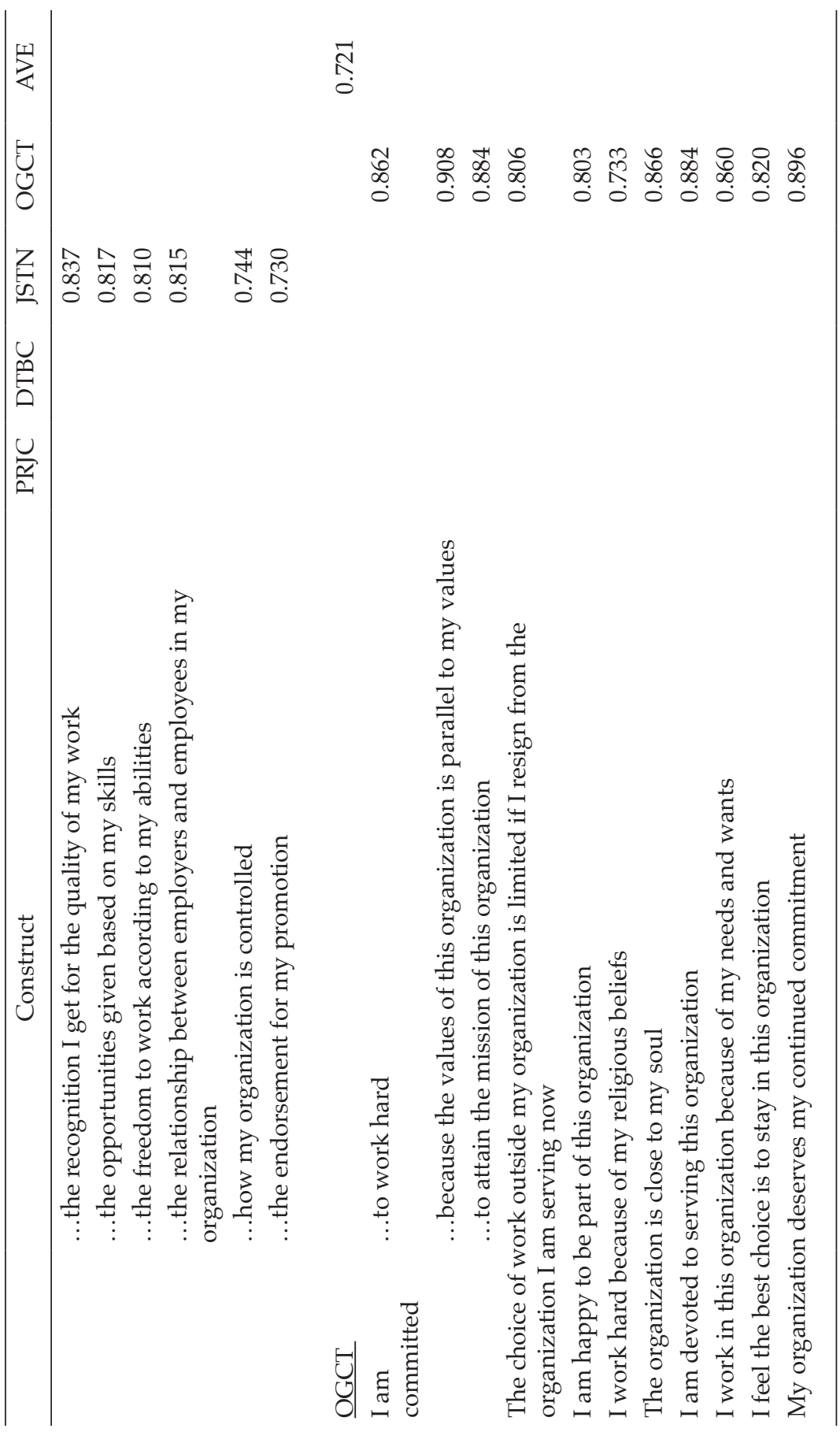


IJMS 27(2), 1-26 (2020)

\section{Measurement Model}

Table 2 displays the correlation of the items and the constructs of the study. All the constructs have loadings of more than 0.70 and Average Variance Extracted (AVE) values for all constructs are greater than 0.50 . These results meet the adequate standards of convergent validity analysis as specified by Hair et al. (2017) and Reinartz et al. (2009).

Table 3 displays the findings of discriminant validity and composite reliability analyses. All constructs have values showing a heterotraitmonotrait (HTMT) ratio of correlation lower than 0.90, while the confidential interval values (in parenthesis) are lower than 1.0 (Hair et al., 2017). The outcomes indicate all constructs fulfil the criteria of discriminant validity analysis. All constructs' composite reliability values are more than 0.80 , signifying all constructs have a great internal consistency (Nunnally \& Bernstein, 1994).

Table 3

Composite Reliability and Discriminant Validity Analyses

\begin{tabular}{cccc}
\hline Construct & \multicolumn{2}{c}{$\begin{array}{c}\text { Heterotrait-Monotrait Ratio of } \\
\text { Correlation }\end{array}$} & \multirow{2}{*}{ Composite Reliability } \\
& JSTN & OGCT & \\
\hline PRJC & 0.248 & 0.150 & 0.960 \\
& $(0.128,0.388)$ & $(0.003,0.287)$ & \\
DTBC & 0.490 & 0.270 & 0.953 \\
& $(0.353,0.611)$ & $(0.123,0.421)$ & 0.959 \\
JSTN & & & 0.966 \\
OGCT & & & \\
\hline
\end{tabular}

Table 4 displays the variance inflation factor (VIF) and descriptive statistics. All constructs having mean values ranging from 4.648 to5.399, show that PRJC, DTBC, JSTN and OGCT have levels ranging from high (4) to highest (7) levels. The coefficient correlations between the independent variables (PRJC and DTBC) and the dependent variables (JSTN and OGCT) have VIF values below 5.0, signifying all constructs do not indicate any major collinearity problem (Hair et al., 2017). Thus, the findings help reaffirm that all constructs fulfil the criteria of validity and reliability analyses. 
Table 4

Variance Inflation Factor and Descriptive Statistics

\begin{tabular}{ccccc}
\hline Construct & Mean & Standard Deviation & \multicolumn{2}{c}{ Variation Inflation Factor } \\
& & & JSTN & OGCT \\
\hline PRJC & 4.760 & 0.915 & 1.938 & 1.938 \\
DTBC & 4.648 & 1.056 & 1.938 & 1.938 \\
JSTN & 5.139 & 0.739 & & \\
OGCT & 5.399 & 0.672 & & \\
\hline
\end{tabular}

\section{Outcomes of Testing the Hypotheses}

Table 5 shows the outcomes of testing Hypotheses 1 and 2, whereby both hypotheses are supported. The addition of PJRC and DTBC in the analysis rationalised 47 percent of the variance in JSTN, in terms of explanatory power. This finding demonstrates that the overall model has a large effect (Cohen, 1988). Other than that, PRJC is significantly and positively correlated with JSTN $(\beta=0.248 ; \mathrm{t}=3.717)$. Similarly, DTBC has a positive and significant correlation with JSTN ( $\beta=0.490$; $\mathrm{t}=0.234$ ). Thus, it is confirmed that PRJC and DTBC act as essential determinants of JSTN.

Table 5

Relationship between Perceived Fairness in Pay Systems and Job Satisfaction

\begin{tabular}{|c|c|c|c|c|}
\hline Hypotheses & $\begin{array}{l}\text { Beta } \\
\text { Value }\end{array}$ & $\begin{array}{c}\mathrm{T} \\
\text { Value }\end{array}$ & $\mathrm{R}^{2}$ & Decision \\
\hline $\begin{aligned} \mathrm{H}_{1}: & \text { Procedural fairness has a positive } \\
& \text { impact on job satisfaction. }\end{aligned}$ & 0.248 & 3.717 & 0.470 & $\begin{array}{l}\text { Large } \\
\text { Effect }\end{array}$ \\
\hline $\begin{array}{l}\mathrm{H}_{2} \text { : Distributive fairness has a positive } \\
\text { impact on job satisfaction. }\end{array}$ & 0.490 & 7.298 & & \\
\hline
\end{tabular}

Note: Significant at *t value $>1.65$ (one tail test)

Apart from hypotheses testing, the study also examined the model fit, effect size, and predictive relevance of the study's model using 
blindfolding and bootstrapping. Results of the bootstrapping test display two essential outcomes: firstly, $\mathrm{f}^{2}$ value of the relationship between PRJC and JSTN is 0.060 , which is greater than 0.02 but lesser than 0.15. This result indicates a weak effect of PRJC on JSTN (Hair et al., 2017). Meanwhile, the correlation between DTBC and JSTN has a $\mathrm{f}^{2}$ value of 0.234 , that is more than 0.15 but less than 0.35 (Hair et al., 2017). This outcome demonstrates a medium effect of DTBC on JSTN. Second, SRMR value has a value of 0.064 , that is less than 0.08 (Hu \& Bentler, 1998), thus demonstrating the model has a good fit. Next, the result of blindfolding test shows that JSTN has a $\mathrm{Q}^{2}$ value of 0.273 , and this value is more than 0 , showing that JSTN has predictive relevance (Hair et al., 2017).

The results of testing Hypotheses 3 and 4 are shown in Table 6. The addition of PJRC and DTBC in the analysis clarifies the 0.15 percent of the OGCT variance. This finding demonstrates that the overall model has moderate effect (Cohen, 1988). Other than that, PRJC is positively and significantly correlated with OGCT $(\beta=0.150 ; t=2.070)$. Similarly, DTBC has a positive and significant correlation with OGCT $(\beta=0.270$; $\mathrm{t}=3.431$ ). Thus, both $\mathrm{H}_{3}$ and $\mathrm{H}_{4}$ are supported.

Table 6

Relationship between perceived fairness in pay systems and organizational commitment

\begin{tabular}{ccccc}
\hline \multicolumn{1}{c}{ Hypotheses } & $\begin{array}{c}\text { Beta } \\
\text { Value }\end{array}$ & $\begin{array}{c}\mathrm{T} \\
\text { Value }\end{array}$ & $\mathrm{R}^{2}$ & Decision \\
\hline $\mathrm{H}_{3}:$ Procedural fairness & 0.150 & 2.070 & 0.152 & $\begin{array}{l}\text { Moderate } \\
\text { has a positive impact } \\
\text { on organizational } \\
\text { commitment. }\end{array}$ \\
$\mathrm{H}_{4}: \begin{array}{l}\text { Distributive fairness } \\
\text { has a positive impact } \\
\text { on organizational } \\
\text { commitment. }\end{array}$ & 0.270 & 3.431 & & \\
\hline
\end{tabular}

Note: Significant at ${ }^{*} \mathrm{t}$ value $>1.65$ (one tail test) 
The results of bootstrapping test display two important findings. First, the relationship between PRJC and OGCT has a value of 0.014 for $\mathrm{f}^{2}$, that is less than 0.02 (Hair et al., 2017). This outcome indicates a weak effect of PRJC on OGCT. Meanwhile, DTBC and OGCT have a correlation value of 0.044 for $\mathrm{f}^{2}$ - greater than 0.02 but less than 0.15 (Hair et al., 2017). This outcome demonstrates a weak effect of DTBC on OGCT. Second, SRMR value has a value of 0.069 , demonstrating a good fit, as it is less than 0.08 (Hu \& Bentler, 1998). Further, the results of blindfolding test show that OGCT has a $\mathrm{Q}^{2}$ value of 0.092 , which is greater than zero (Hair et al., 2017), illustrating predictive relevance for OGCT.

\section{Discussion}

These findings demonstrate that perceived fairness in pay systems is indeed an important determinant of positive work-related attitude. In the context of this research, the studied organization is a Malaysian public audit agency which follows the remuneration guidelines issued by the PSD, Malaysia. The remuneration guidelines guide the management to use standard remuneration principles in distributing and allocating pay (monetary and non-monetary payments) to all employees in the organization. For example, formal rules and regulations are normally used to guide the management in making fair pay decisions, such as by avoiding political behaviour in performance assessments and using standardized pay policies for all employees. The formal rules are meant to facilitate the administration of the formal processes and systems of pay allocation and distribution, based on the level, type, and/or quantum of pay according to job functions (e.g., yearly salary increases and non-monetary benefits based on job structure) and/or performance (e.g., yearly honorarium and recognition certificates for high performers). These formal rules are viewed as an important instrument to ensure equity in fulfilling employees' needs and expectations. The majority of respondents in this study view the levels of PRJC, DTBC, JSTN, and OGCT as high. This view sends a signal that a higher perceived fairness in pay systems may result in improved job satisfaction and organizational commitment in the organization.

This study supports the notion of Leventhal's (1980) Procedural Fairness Theory, by providing empirical evidence that perceived 
procedural fairness and perceived distributive fairness in pay system are important determinants of work-related attitude. The predicting variable of procedural fairness is consistent with the notion of Leventhal's (1980) Procedural Fairness Theory, which posits that fair pay decisions (i.e., with consistency, impartiality, accuracy, representativeness, correctability and ethical standards) will lead to employees' heightened feeling of procedural fairness, that in turn, will lead to organizational commitment and greater job satisfaction. The essence of this theory has been supported in several studies by Choong et al. (2010), Kristanto (2015), Al-Zu'bi (2010), Aslam (2012), and Rehman et al. (2015).

Conversely, the predicting role of distributive fairness has received strong support from the essence of Adam's (1963) Equity Theory, which postulates that allocation of employees' output (e.g., type, level and/or value of pay) equal to their input (e.g., effort, contribution and/or performance) will invoke employees' perceptions of distributive fairness, which may lead to a higher positive workrelated attitude, especially towards organizational commitment and job satisfaction in the organization. The essence of these theories has also been supported in other studies, including Al-Zu'bi (2010), ClayWarner et al. (2005), Khattak et al. (2017), and Rehman et al. (2015).

Results of this research offer useful insights for managers to improve their own organization's pay management system. In order to find appropriate solutions, the importance-performance map analysis (IPMA) generated via SmartPLS is used to help practitioners in determining priority actions for overcoming managerial problems (Hair et al., 2017). Results of our analysis display two important outcomes. First, distributive fairness has the highest relevance to job satisfaction (0.352), but scores the lowest on job satisfaction (61.405). Meanwhile, procedural fairness has the lowest importance to job satisfaction (0.200), but scores the highest on job satisfaction (61.781). Second, distributive fairness shows the highest relevance to organizational commitment (0.191), but the lowest to organizational commitment (61.405). Finally, procedural fairness has the lowest importance for organizational commitment (0.109), but the highest score for organizational commitment (61.781).

These findings send several signals; including that there is a great potential to expand on the performance of distributive fairness in the 
organization. Some recommended actions to enhance distributive fairness in pay system are: first, managers should be trained to practice fairness rules and avoid political behaviour when making pay decisions. This practice will strongly invoke employees' positive perception and decrease their prejudices about appraisal systems, among others. Consequently, this condition will motivate employees to enhance their career well-being in organizations.

Second, human-oriented leadership practices should be highly promoted among managers to ensure that managers deal with issues related to employees in a better way. For example, consultation and participation styles in pay allocation (e.g., information sharing, good interaction, open feedback and suggestions) will facilitate employees to plan their career path (e.g., performance-based reward and promotion). These positive reinforcements would eventually decrease employees' complaints and their deviance behaviour. In addition, past studies have indicated that issues of low level of service or work quality demonstrated by employees can be attributable to low employees' commitment (Yahya et al., 2008). Hence, it is imperative for managers to ensure that employees are highly committed by ascertaining, among others, that the pay system is properly and adequately managed. Ensuring a high level of organizational commitment among the employees is especially critical for the public sector due to the increasing demands from the members of the public in general for these agencies to offer better quality and more flexible services to cater to the constantly changing environment of today and the more complex challenges.

Third, employee contributions should be appropriately recognized by using two major types of award bases, namely performancebased reward and job-based reward. By offering performance-based reward, such as monetary bonus, the management can appreciate the performance of each employee, such as high, moderate or low performance. Meanwhile, job-based reward is important to appreciate employees' commitment to the organization, their wisdom and experience, as well as their ability to perform their daily job. These award bases are equally important and may complement each other in enhancing employees' perception of fairness of the pay system. If these suggestions are seriously considered, more positive attitudinal and behavioral outcomes may be achieved (e.g., trust, loyalty, ethics and work quality) in the organization. 


\section{Conclusion}

The confirmatory factor analysis indicates that the measurement scale adequately fulfils the criteria of validity and reliability. The SmartPLS path model analysis confirms that perceived fairness in the pay system, indeed acts like a vital predictor of positive work-related attitude in the examined organization. Hence, the current research is of the view that procedural fairness and distributive fairness should be incorporated as critical dimensions in the pay management system. This research further suggests that employees' perceived fairness of pay procedure and value of distribution will strongly inspire positive employee attitude, such as extra role behaviour, compliance with the law and trust of the organization. Therefore, positive attitude may help in maintaining and achieving organizational competitiveness and performance during economic turbulence and globalization.

However, the study has some limitations. Firstly, it does not assess all aspects or features of the variables of interest. Secondly, the crosssectional research design employed in this study is inadequate to assess a detailed causal relationship among different employee groups within the sample. Thirdly, the influence of respondent characteristics in the correlation amongst variables of interest was not assessed. Finally, monitoring of response bias was not possible with purposive sampling utilized in this study. Due to these limitations, one can only generalize with caution.

This study offers several suggestions to strength future research. First, respondents' features, such as gender, age, education and position in the organization, can be examined as it might provide an explanation on how differences and similarities of respondents' perception may indirectly affect the correlation between perceived fairness in pay system and work-related attitude. Second, a longitudinal research design is perhaps a suitable approach for researchers to compare the relationship between perceived fairness in pay system and workrelated attitude in various organizations. Third, other dimensions of perceived fairness in the pay system, such as interpersonal communication, information fairness, award basis and value of pay, could be considered as well because they have often been discussed in extant literature on organizational fairness. Finally, other specific 
indicators of work-related attitude, like extra role behaviour, compliance with the law, and ethical behaviour can be considered in future investigations as they are normally recognized as important outcomes of perceived fairness in pay system.

\section{Acknowledgement}

This work is supported by the FRGS/1/2014/SS05/UKM/02/7, MyBrain Scholarship and CRIM UKM.

\section{REFERENCE}

Abbasi, A. S., \& Alvi, A. K. (2012). Impact of organizational justice on employee engagement in banking sector of Pakistan. MiddleEast Journal of Scientific Research, 12(5), 643-649.

Adams, J. S. (1963). Wage inequities, productivity, and work quality. Industrial Relations, 3, 9-16.

Adams, J. S. (1965). Inequity in social exchange. Advances in Experimental Social Psychology, 2, 267-299.

Ali, M., \& Saifullah, Z. (2014). Distributive and procedural justice as predictors of job satisfaction and organizational commitment: A case study of banking sector of Balochistan. Journal of Information Engineering and Applications, 4(11), 25-29.

Allen, N. J., \& Meyer, J. P. (1990). The measurement and antecedents of affective, continuance and normative commitment to the organization. Journal of Occupational Psychology, 63, 1-18.

Allen, N. J., \& Meyer, J. P. (1996). Affective, continuance, and normative commitment to the organization: An examination of construct validity. Journal of Vocational Behavior, 49(3), 252-276.

Al-Zu'bi, H. A. (2010). A study of relationship between oganizational justice and job satisfaction. International Journal of Business and Management, 5(12), 102-106.

Anuar, A. Ismail, A., \& Abdin, F. (2014). Administrator's role in performance pay system as a determinant of job satisfaction. UTM Sains Humanika, 11-17.

Aslam, R. (2012). Investigating the relationship of OCB with job satisfaction, organizational commitment and turnover intentions. Management Journal, 1(9), 90-100. 
Bakhshi, A., Kumar, K., \& Rani, E. (2009). Organizational justice perceptions as predictor of job satisfaction and organization commitment. International Journal of Business and Management, 4(9), 145-150.

Burck, H. D., \& Peterson, G. W. (1983). Doctoral comprehensive examinations in one program: A descriptive and evaluative study. Counselor Education and Supervision, 23, 169-172.

Choong, K. F., Wong, E. S. K., \& Tioh, N. H. (2010). The impact of organizational justice on employees' job satisfaction: The Malaysian companies perspectives. American Journal of Economics and Business Administration, 2(1), 56-63.

Clay-Warner, J., Reynolds, J., \& Roman, P. (2005). Organizational justice and job satisfaction: A test of three competing models. Social Justice Research, 18(4), 391-409.

Cloutier, J., \& Vilhuber, L. (2008). Procedural justice criteria in salary determination. Journal of Managerial Psychology, 23(6), 713-740.

Cohen, J. (1988). Statistical power analysis for the behavioural sciences. Hillsdale, NJ: Lawrence Erlbaum Associates.

Cohen-Charash, Y., \& Spector, P. E. (2001). The role of justice in organizations: A meta-analysis. Organizational Behavior and Human Decision Processes, 86(2), 278-321.

Colquitt, J., LePine, J., \& Wesson, M. (2017). Organizational behaviour: Improving performance and commitment in the workplace (5th ed.). Stanford, California, Stanford University Press.

Colquitt, J. A., Zapata-Phelan, C. P., \& Roberson, Q. M. (2005). Justice in teams: A review of fairness effects in collective contexts. In Martocchio J. J. (Ed.), Research in Personnel and Human Resources Management, 24, 53-94.

Colquitt, J. A. (2001). On the dimensionality of organizational justice: A construct validation of a measure. Journal of Applied Psychology, 86, 386-400.

Colquitt, J. A., Conlon, D. E., Wesson, M. J., Porter, C. O. L. H., \& Ng, K. Y. (2001). Justice at the millennium: A meta-analytic review of 25 years of organizational justice research. Journal of Applied Psychology, 86, 425-445.

Creswell, J. W. (2014). Research design: Qualitative, quantitative, and mixed methods approaches (2nd ed.). California: Sage Publications.

Cropanzano, R., \& Ambrose, M. L. (2001). Procedural and distributive justice are more similar than you think: A monistic perspective and a research agenda. Stanford, California, Stanford University Press. 
Eichhorn, B. R. (2014). Common method variance techniques (Paper AA11-2014 Common). Cleveland State University, Department of Operations \& Supply Chain Management. Cleveland, $\mathrm{OH}$, SAS Institute.

Erdogan, B., Kraimer, M. L., \& Liden, R. C. (2001). Procedural justice as a two-dimensional construct. Journal of Applied Behavioral Science, 37(2), 205-22.

Folger, R., \& Cropanzano, R. (1998). Organizational Justice and human resource management. Thousand Oaks, CA: Sage Publications.

George, J., \& Wallio, S. (2017). Organizational justice and millennial turnover in public accounting. Employee Relations, 39(1), 112126.

Greenberg, M. T., Weissberg, R. P., O'Brien, M. U., Zins, J. E., Fredericks, L., Resnik, H., \& Elias, M. J. (2003). Enhancing school-based prevention and youth development through coordinated social, emotional, and academic learning. American Psychologist, 58(67), 466-474.

Hair, J. F., Hult, G. T. M., Ringle, C. M., \& Sarstedt, M. (2017). A primer on partial least squares structural equation modeling (PLS-SEM). Thousand Oaks, CA: Sage Publications.

Hamidun, H. (2009). The influence of training on employee's work commitment and performance (Unpublished Master Thesis). University of Malaya.

Hu, L., \& Bentler, P. M. (1998). Fit Indices in covariance structure modeling: Sensitivity to underparameterized model misspecification. Psychological Methods, 3, 424-453.

Ikramullah, M., Shah, B., Hassan, F. S. U., Zaman, T., \& Khan, H. (2011). Fairness perceptions of performance appraisal system: An empirical study of civil servants in district Dera Ismail Khan, Pakistan. International Journal of Business and Social Science, 2(21), 92-100.

Ismail, A., Madrah, H., Aminudin, N., \& Ismail, Y. (2013). Mediating role of career development in the relationship between career program and personal outcomes. Makara, Seri Sosio Humaniora, 17(1), 43-54.

Ismail, A., \& Razak, M. R. A. (2017). Performance-based reward administration enhancing employees' feelings of interactional justice. Studies in Business and Economics, 12(1), 5-18.

Jaros, S. (2007). Meyer and Allen model of organizational commitment: Measurement issues. The ICFAI Journal of Organizational Behaviour, 7(4), 7-25. 
Khattak, M. A., Sindhu, M. I., Haider, A., \& Urooj, S. F. (2017). Impact of procedural justice on organizational commitment with moderating effect of pay satisfaction. Jinnah Business Review, $5(2), 54-60$.

Kristanto, H. (2015). Keadilan organisasional, komitmen organisasional, dan kinerja karyawan. Jurnal Manajemen dan Kewirausahaan, 86-98.

LaMastro, V. (1999). Commitment and perceived organizational support. National Forum of Applied Education Research Journal, 12(3), 1-13.-

Leventhal, G. S. (1980). What should be done with equity theory? New approaches to the study of fairness in social relationship. In K. J. Gergen, M. S. Greenberg, \& R. H. Willis (Eds.), Social exchange: Advances in theory and research (pp. 27-55). New York: Plenum.

Martocchio, J. J. (2019). Human resource management (15th ed.). UrbanaChampaign, United States, Pearson.

Mas'ud, F. (2004). Survai diagnosis organisasional konsep dan aplikasi. Semarang, Universitas Diponegoro.

Milkovich, G. T., \& Newman, J. M. (2009). Compensation. New York: McGraw-Hill Irwin.

Misener, T. R., Haddock, K. S., Gleaton, J. U., \& Ajamieh, A. R. A. (1996). Toward an international measure of job satisfaction. Nursing Research, 45, 87-91.

Moorman, R. H., Blakely, G. L., \& Niehoff, B. P. (1998). Does perceived organizational support mediate the relationship between procedural justice and organizational citizenship behaviour. Academy of Management, 41(3), 351-357.

Mowday, R. T., Porter, L. W., \& Steers, R. M. (1982). Employeeorganization linkages. New York: Academic Press.

Munir, S., Aziz, A., Shaladin, M., \& Muhammad, A. S. A. H. (2013). Fairness of performance appraisal and organizational commitment. Asian Social Science, 9(2), 121-128.

Nabatchi, T., Bingham, L. B., \& Good, D. H. (2007). Organizational justice and workplace mediation: A six-factor model. International Journal of Conflict Management, 18(2), 148-174.

Naqvi, S. M. M. R., Kanwal, N., Ishtiaq, M., \& Ali, M. (2013). Impact of job autonomy on organizational commitment: Moderating role of job satisfaction in tobacco industry of Pakistan. Far East Journal of Psychology and Business, 12(5), 57-72. 
Newman, C. L., Cinelli, M. D., Vorhies, D., \& Folse, J. A. G. (2019). Benefitting a few at the expense of many? Exclusive promotion and their impact on untargeted customer. Journal of the Academy of Marketing Science, 47, 76-96.

Nunnally, J. C., \& Bernstein, I. H. (1994). Psychological theory. New York: MacGraw-Hill.

Podsakoff, P. M., MacKenzie, S. B., Lee, J. Y., \& Podsakoff, N. P. (2003). Common method biases in behavioural research: A critical review of the literature and recommended remedies. Journal of Applied Psychology, 88(5), 879-903.

Public Service Department. (2018). Annual Report 2018. Retrieved from https: / / www.jpa.gov.my.

Rahman, A., Shahzad, N., Mustafa, K., Khan, M., \& Qurashi, F. (2016). Effects of organizational justice on organizational commitment. International Journal of Economics and Financial Issues, 6(3), 188196.

Razak, M. R. A., \& Ismail, A. (2018). The mediating effect of procedural justice on the relationship between performancebased remuneration management and job satisfaction. Jurnal Pengurusan (UKM Journal of Management), 19-28.

Rehman, Z., Rehman, K., Khan, S. D., Saeed, M., Adeel, M., \& Tariq, M. (2015). Effect of procedural justice on organizational commitment: Evidence from Pakistan. European Journal of Business and Management, 7(10), 278-280.

Reinartz, W., Haenlein, M., \& Henseler, J. (2009). An empirical comparison of the efficacy of covariance-based and variancebased SEM. International Journal of Research in Marketing, 26(4), 332-344.

Robbins, S. P., \& Judge, T. A. (2007). Organizational behaviour (12th ed.). NJ, Pearson: Prentice Hall.

Sareshkeh, S. K., Ghaziani, F. G., \& Tayebi, S.M. (2012). Impact of organizational justice perceptions on job satisfaction and organizational commitment: The Iranian Sport Federations perspective. Annals of Biological Research, 3(8), 4229-4238.

Sekaran, U., \& Bougie, R. (2013). Research methods for business: A skillbuilding approach (6th ed.). Hoboken: John Wiley and Sons.

Singh, A., \& Sharma, T. R. (1999). Manual for job satisfaction. Agra: National Psychology Corporation.

Walsh, M.B. (2003). Perceived fairness of and satisfaction with employee performance appraisal (Unpublished doctoral dissertation). The Louisiana State University. 
IJMS 27(2), 1-26 (2020)

Warr, P. B., Cook, J., \& Wall, T. D. (1979). Scales for the measurement of some work attitudes and aspects of psychological well-being. Journal of Occupational Psychology, 52, 129-148.

Yahya, K. K., Johari, J., Adnan, Z., Mohd-Isa, M. F., \& Daud, Z. (2008). Faktor-faktor yang mempengaruhi komitmen dalam kalangan penjawat awam. International Journal of Management Studies, 15, 199-223. 